\title{
STRATEGI PENGEMBANGAN BISNIS BERBASIS MENU ENGINEERING DI KAMBING SOON RESTO AND CAFE BANDUNG
}

\author{
Imam Ardiansyah, ${ }^{1)}$, Vania Magdalena ${ }^{2)}$ \\ 1) Universitas Bunda Mulia \\ 2) Akademi Pariwisata NHI Bandung
}

\begin{abstract}
Bandung city is a tourist destination city that has a choice of various culinary both traditional and international. One of the Resto and Cafe in Bandung is Kambing Soon Resto and Cafe located at Jl. IR H Djuanda. One of the factors that become the main force for business in the field of this restaurant is the menu, even the menu can also be the identity of the restaurant terebut. A good menu can be seen from the level of sales and ability to provide benefits or the level of popularity and profitability. Based on these conditions, the researcher aims to analyze the engineering menu, the research was conducted in August 2017 until November 2017. The method used is the analysis of margin contribution and analysis of popularity index, menu classification, and SWOT analysis.Based on the analysis for 4 months, the results obtained are 32 food menu that the researcher carefully is the category of stars consists of 7 menus with percentage of $21.88 \%$, plowhorses category consists of 11 menus with percentage of 34.37\%, the category consists of puzzles 4 menus with percentage of $12.50 \%$, dogs category consists of 10 menus with a percentage of $31.25 \%$.
\end{abstract}

Keywords: Menu Engineering, Business Development

\begin{abstract}
ABSTRAK
Kota Bandung merupakan kota tujuan wisata yang yang memiliki pilihan beragam kuliner baik tradisional maupun internasional. Salah satu yang Resto dan Cafe yang ada di Bandung adalah Kambing Soon Resto dan Cafe yang terletak didaerah Jl. IR H Djuanda. Salah satu faktor yang menjadi kekuatan utama bagi usaha di bidang restoran ini adalah menu, bahkan menu juga bisa menjadi identitas dari restoran terebut. Menu yang baik dapat dilihat dari tingkat penjualan dan kemampuannya dalam memberikan keuntungan atau tingkat popularitas dan profitabilitasnya. Berdasarkan kondisi tersebut, penulis bertujuan untuk menganalisis тепи engineering, penelitian ini dilaksanakan pada bulan Agustus 2017 hingga November 2017. Metode yang digunakan adalah analisis kontribusi marjin dan analisis indeks popularitas, klasifikasi menu, dan anlisis SWOT. Berdasarkan analisis selama 4 bulan, maka hasil yang diperoleh adalah 32 menu makanan yang penulis teliti adalah kategori stars terdiri dari 7 menu dengan persentase sebesar 21,88\%, kategori plowhorses terdiri dari 11 menu dengan persentase sebesar $34,37 \%$, kategori puzzles terdiri dari 4 menu dengan persentase sebesar $12,50 \%$, kategori dogs terdiri dari 10 menu dengan persentase sebesar $31,25 \%$.
\end{abstract}

Kata Kunci: Rekayasa Menu, Pengembangan Bisnis

\section{PENDAHULUAN}

Industri pariwisata dewasa ini merupakan industri yang sedang digalakan oleh pemerintah disamping industri hasil alam yang memiliki peranan penting dalam perekonomian Indonesia. Paradigma pembangunan beberapa negara kini lebih berorientasi kepada pengembangan sektor jasa dan industri, termasuk di dalamnya adalah industri pariwisata. Salah satu fasilitas yang mendukung kegiatan wisata adalah usaha jasa yang menyediakan makanan dan minuman atau lazimnya disebut dengan restoran. Definisi restoran menurut Ninemeier dan Hayes (2006:16) adalah "Suatu operasi pelayanan makanan yang mendatangkan keuntungan yang mana basis utamanya termasuk di dalamnya adalah penjualan makanan dan minuman kepada individuindividu dan tamu-tamu dalam kelompok kecil".

Salah satu faktor yang menjadi kekuatan utama bagi usaha di bidang restoran ini adalah menu, bahkan menu juga bisa menjadi identitas dari restoran terebut. Sebuah menu yang baik dapat menjadi sumber pemasukan utama bagi restoran dan dapat menjadi modal bagi suatu restoran 
untuk bertahan cukup lama bahkan sampai bertahun-tahun. Oleh karena itu kemampuan untuk menentukan menu sangat menentukan kesuksesan dari bisnis kuliner, seperti yang dikemukakan oleh Ninemeir (1990:103), yaitu "There is a belief in the food service industry that everything starts with the menu". Yang dapat diartikan bahwa ada suatu keyakinan dalam industri jasa makanan bahwa semuanya bermula dari menu. Bahkan sebelum dapur atau restoran itu dibangun, daftar menu sudah harus dibuat atau dipikirkan terlebih dahulu.

Sebagai faktor penting dalam menunjang keberhasilan usaha restoran untuk menjual makanan dan minuman, sebuah menu harus dipilih dengan baik, dari segi rasa, tampilan dan harga yang menarik bagi konsumen dan juga tentunya harus memberikan keuntungan bagi restoran. Selain sebagai salah satu alat menawarkan produk, dalam usaha restoran suatu menu juga perlu mendapatkan pengevaluasian. Hal ini bertujuan untuk membantu pihak manajemen dalam perencanaan menu selanjutnya. Selain itu dengan adanya proses pengevaluasian menu, pihak manajemen dapat mengetahui apabila adanya menu yang kurang populer, sehingga pihak manajemen dapat langsung melakukan tindakan terhadap permasalahan tersebut.

Suatu produk memiliki suatu masa yang disebut Life Cycle, dimana suatu produk akan mengalami masa product development, introduction, growth, maturity yang akhirnya tidak dapat berkembang lagi dan bisa dilupakan atau decline.

*Korespondensi Penulis:

E-mail: iardiansyah@ubm.ac.id

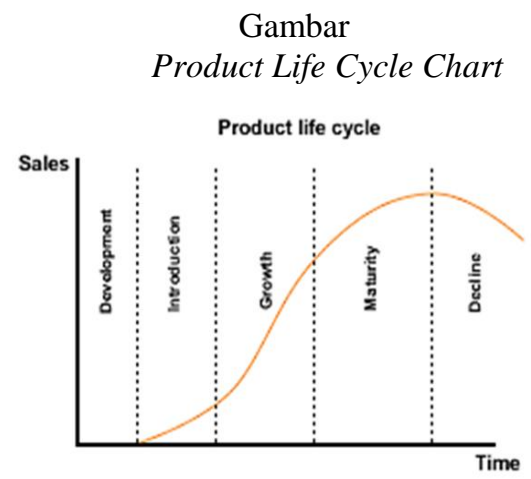

Sumber: Philip Kotler \& Gary Armstrong, 2008

Berdasarkan grafik tersebut, maka, diperlukan upaya untuk menjaga menu tersebut supaya tidak mengalami penurunan atau decline. Dengan memantau menu yang ditawarkan diharapkan usaha restoran tidak dilupakan oleh pelanggan karena telah mengantisipasi permasalah Life Cycle menu yang ditawarkan.

Menu yang baik dapat dilihat dari tingkat penjualan dan kemampuannya dalam memberikan keuntungan atau tingkat popularitas dan profitabilitasnya. Seperti yang diungkapkan oleh Ninemeir dalam bukunya yang berjudul Planning and Control for the Food and Beverage Operation (2009:113) "There two factors measure of how to good menu is: its popularity and its profitability". Pernyataan tersebut menunjukkan ada 2 (dua) tolak ukur suatu menu dapat dikatakan baik yaitu dari segi popularitas dan dari segi keuntungannya.

Untuk melihat hubungan kedua parameter tersebut perlu dibuat perbandingan yang dapat memberikan kesimpulan tentang kedudukan setiap jenis makanan dalam bauran menu yang ditawarkan. Sehingga akan didapat suatu kategori tentang kemampuan dari item menu makanan tersebut. Seperti yang diungkapkan oleh Ninemeir (1991:106) bahwa, "with these tools of menu engineering manager can evaluate profitability of menu items and classify them as either stars, plowhorse, puzzles or dogs". Yang bisa diartikan dengan menu engineering seorang manager dapat mengevaluasi keuntungan dan 
mengklasifikasikan menu menjadi kelompok stars, plowhorses, puzzles atau dogs
Berdasarkan uraian yang terurai pada latar belakang penelitian, berikut rumusan masalah

Tabel 1

Hasil Penjualan Kambing Soon Resto \& Café Bandung

\begin{tabular}{|c|c|c|c|c|c|c|c|c|c|c|c|c|}
\hline Nama Menu & Maret & April & Hasil & Mei & Hasil & Juni & Hasil & Juli & Hasil & Ags & Hasil & Total \\
\hline \multicolumn{13}{|l|}{ Hot Grilled } \\
\hline Total Keseluruhan & 110 & 116 & $5.45 \%$ & 104 & $-10.34 \%$ & 105 & $0.96 \%$ & 102 & $-2.86 \%$ & 89 & $-12.75 \%$ & $-19.10 \%$ \\
\hline \multicolumn{13}{|l|}{ Lamb Favorites } \\
\hline Total Keseluruhan & 84 & 97 & $15.48 \%$ & 91 & $-6.19 \%$ & 82 & $-9.89 \%$ & 83 & $1.22 \%$ & 76 & $-8.43 \%$ & $-7.81 \%$ \\
\hline \multicolumn{13}{|l|}{ Common Favorites } \\
\hline Total Keseluruhan & 95 & 95 & $0.00 \%$ & 100 & $5.26 \%$ & 86 & $-14.00 \%$ & 95 & $10.47 \%$ & 87 & $-8.42 \%$ & $-6.69 \%$ \\
\hline \multicolumn{13}{|l|}{ Nasi Goreng } \\
\hline Total Keseluruhan & 103 & 91 & $-11.65 \%$ & 102 & $12.09 \%$ & 123 & $20.59 \%$ & 115 & $-6.50 \%$ & 91 & $-20.87 \%$ & $-6.35 \%$ \\
\hline \multicolumn{13}{|l|}{ Cemilan } \\
\hline Total Keseluruhan & 133 & 159 & $19.55 \%$ & 134 & $-15.72 \%$ & 114 & $-14.93 \%$ & 132 & $15.79 \%$ & 116 & $-12.12 \%$ & $-7.43 \%$ \\
\hline
\end{tabular}

Sumber: General Manager Kambing Soon Resto \& Café Bandung \& Hasil Olahan

Peneliti

Berikut adalah data yang didapatkan oleh penulis dari pihak Kambing Soon dan telah diolah oleh penulis yang menunjukkan bahwa adanya permasalahan yang berhubungan dengan menu yang ditawarkan, yaitu data hasil penjualan makanan Kambing Soon Resto \& Café Bandung.

Berdasarkan data hasil penjualan bahwa dari setiap kategori menu yang ditawarkan selama 6 bulan, terhitung dari bulan Maret - Agustus 2017, setiap bulannya mengalami penurunan. Kategori Hot Grilled sebesar -19.10\%, Lamb Favorites sebesar -7.81\%, Common Favorites sebesar $-6.69 \%$, Nasi Goreng sebesar $-6.35 \%$, dan Cemilan sebesar $-7.43 \%$.

Sehingga dari data tersebut yaitu data hasil penjualan, penulis menganalisa bahwa permasalahan yang terjadi yaitu adanya kejenuhan terhadap menu yang ditawarkan atau menu tersebut sudah mengalami tahap decline yang berarti menu tidak berkembang, karena mengingat usia berdirinya Kambing Soon yang sudah berjalan kurang lebih 6 tahun.

\section{Perumusan masalah}

penelitian ini adalah sebagai berikut :

1. Bagaimana Indeks Popularitas di Kambing Soon Resto \& Café Bandung?

2. Bagaimana Marjin Kontribusi di Kambing Soon Resto \& Café Bandung?

3. Bagaimana Klasifikasi Menu Makanan di Kambing Soon Resto \& Café Bandung?

4. Bagaimana Strategi Pengembangan Bisnis di Kambing Soon Resto \& Cafe Bandung?

\section{Tujuan penelitian}

Penelitian ini bertujuan :

1. Untuk mengetahui indeks popularitas menu makanan di Kambing Soon Resto \& Café Bandung.

2. Untuk mengetahui marjin kontribusi menu makanan di Kambing Soon Resto \& Café Bandung.

3. Untuk mengetahui klasifikasi menu makanan di Kambing Soon Resto \& Café Bandung. 
4. Untuk menentukan Strategi Pengembangan Bisnis di Kambing Soon Resto \& Cafe Bandung.

\section{TINJAUAN PUSTAKA}

Evaluasi menu dapat dilakukan dengan cara menganalisa tingkat kepopuleran dan tingkat keuntungan yang didapat oleh perusahaan dari setiap produk yang dijual. Seperti yang dikemukakan oleh Scanlon (2000:174) yaitu: "Item sales are recorded over an establishment period of time and evaluated on the basis two major factors : popularity and contribution to sales". Untuk mengetahui sejauh mana suatu menu itu populer, dapat dilakukan dengan mencatat dan menganalisa jumlah penjualan dari menu yang ditawarkan. Sales history adalah sebuah format untuk merekapitulasi penjualan selama suatu periode. Seperti yang dijelaskan oleh Miller, Hayes, dan Dopson (2002:29) yaitu: "A sales history is the systematic recording of all sales achieved during a predetermined time period". Pengertian diatas dapat diartikan bahwa sales history adalah catatan sistematik dari semua hasil penjualan yang diperoleh dalam periode tertentu. Seperti yang diungkapkan oleh Suyono (2004:73) "Dari data jumlah penjualan (sales history) akan digunakan untuk membandingkan masing-masing porsi makanan terhadap kategori makanan keseluruhan. Perbandingan ini dalam bentuk ratio dan hasil yang diperoleh merupakan indeks popularitas jenis makanan yang bersangkutan". Maka sales history merupakan data yang akan digunakan untuk menghitung indeks popularitas yang digunakan sebagai acuan.

Setelah mengetahui jumlah penjualan dari sales history, kita akan menghitung popularity index yang diharapkan dari masing-masing menu. Indeks popularitas dapat dihitung dengan membagi jumlah porsi yang terjual dari satu jenis menu dengan total porsi yang terjual dari semua menu. Seperti yang dikemukakan oleh Dittmer (2003:187) yaitu: "Popularity index is defined as the ratio of portion sales for a given menu item to total portion sales for all menu items. The popularity index is calculated by dividing portion sales for a given item by the total portion sales for all menu items".

Untuk menentukan tingkat kepopuleran dari suatu menu diperlukan dasar untuk mengukurnya, seperti yang dikemukakan oleh Ninemeier (2009:115) yaitu: "The basis for measuring the degree of popularity of each menu item is called popularity index. This index is based upon the nation of expected popularity. For the purpose analysis, each menu items is expected to contribute an equal share of total menu sales. Therefore, the expected popularity of each menu items is calculated by simply dividing $100 \%$ by the number of menu items on the menu".

Dapat diartikan bahwa dasar untuk mengukur popularitas yang diharapkan dari setiap menu disebut indeks popularitas. Indeks ini berdasarkan dugaan dari popularitas yang diharapkan. Untuk tujuan analisis, masing-masing menu diharapkan dapat memberikan bagian yang sama dari total penjualan. Popularitas yang diharapkan dari setiap menu, didapatkan dengan membagi $100 \%$ dengan jumlah menu yang ada pada menu. Oleh karena itu, popularitas yang diharapkan dari masing-masing menu dihitung dengan membagi $100 \%$ dengan jumlah menu yang ada pada suatu kategori.

Menurut Ninemeier (2009:116) yaitu "Menu engineering that the item is popular if it's sales equal $70 \%$ of what expected. Thus, the popularity index for items on a given menu is defined as $70 \%$ of expected popularity of each item menu". Teori tersebut dapat diartikan bahwa suatu menu dapat dikatakan populer apabila penjualannya telah mencapai $70 \%$ dari rata-rata dalam setiap kategorinya. Indeks popularitas dari suatu menu adalah sebesar $70 \%$ dari popularitas yang diharapkan dari suatu kategori menu.

Selanjutnya adalah menentukan menu mix percentage dari masing-masing menu. Definisi menu mix percentage menurut Coltman dan Jagles (2001:252) adalah "Menu mix percentage is converts the number sold of each menu item into a percentage of all items sold. The quantity sold of each item is divided 
by the total of all items sold then multiplied by 100". Dari pernyataan tersebut dapat diketahui bahwa menu mix percentage adalah persentase jumlah penjualan dari setiap menu, yang didapat dengan cara membagi jumlah porsi yang terjual dari masing-masing menu dengan total dari seluruh menu yang terjual kemudian dikali dengan 100.

Coltman dan Jagles (2001:255) menyatakan tentang menu mix category yaitu: "MM \% Category: Record either an $H$ (for High) or L (for Low). These definitions are made by comparing each menu item's Menu Mix Percentage with the average popularity of all menu items. If the figure Menu Mix \% is higher than the average, an $H$ is recorded; and if it is less than average, an $L$ is recorded".

Penyataan tersebut dapat diartikan bahwa sebuah menu dapat digolongkan pada kategori High apabila menu mix \% dari suatu menu lebih besar dari rata-rata popularitas seluruh menu, sebaliknya sebuah menu dapat digolongkan pada kategori Low apabila menu mix \% dari suatu menu lebih rendah dari ratarata popularitas seluruh menu.

Marjin kontribusi adalah data yang digunakan untuk mengetahui tingkat profitabilitas suatu menu. Dalam marjin kontribusi ada dua faktor penentu yaitu food cost dan selling price. Ninemeir (1990:105) menyatakan bahwa: "Contribution margins are calculated by subtracting food cost from revenue." Yang dapat diartikan $\mathrm{CM}$ dihitung dengan mengurangi biaya makanan dari total pendapatan. Hal ini juga didukung oleh Suyono (2004:74) bahwa: "Profitabilitas makanan dihitung dengan menggunakan parameter laba kotor (contribution margin) yang diperoleh dengan mengurangi biaya bahan per-posi (food cost per-portion) terhadap harga jual (selling price)".

Menu dapat dievaluasikan dengan menganalisis popularitas dan kemampuan masing - masing jenis makanan dan minuman pada sebuah menu dalam memberikan kontribusi keuntungan, seperti yang diungkapkan oleh. Ninemeir (1990:114), yaitu: "Menu items can be evaluated in terms of both their popularity and profitability". Setelah sebuah menu telah diketahui tingkat popularitas dan profitabilitasnya, maka sebuah menu dapat dimasukkan ke dalam suatu lembar kerja yang disebut lembar kerja rekayasa menu atau menu engineering worksheet.

Setiap menu diklasifikasikan dalam empat kategori, yaitu Stars, Plowhorses, Puzzles, dan Dogs. Kategori tersebut diklasifikasikan berdasarkan tingkat popularitas dan tingkat contribution margin dari suatu menu. Menu yang memiliki tingkat contribution margin yang lebih tinggi dari rata-rata contribution margin dan tingkat popularitas yang lebih tinggi dari rata-rata popularity diklasifikasikan ke dalam kategori Stars. Kategori Plowhorses adalah menu yang memiliki tingkat contribution margin yang lebih rendah dari rata-rata contribution margin dan tingkat popularitas yang lebih tinggi dari rata-rata popularity. Sedangkan kategori Puzzles adalah menu yang memiliki tingkat contribution margin yang lebih tinggi dari rata-rata contribution margin dan tingkat popularitas yang lebih rendah dari rata-rata popularity. Kategori yang terakhir adalah kategori Dogs, yang termasuk kedalam kategori tersebut adalah menu yang memiliki tingkat contribution margin yang lebih rendah dari rata-rata contribution margin dan tingkat popularitas yang lebih rendah dari rata-rata popularity.

Gambar 1 Menu Engineering Classification Sheet

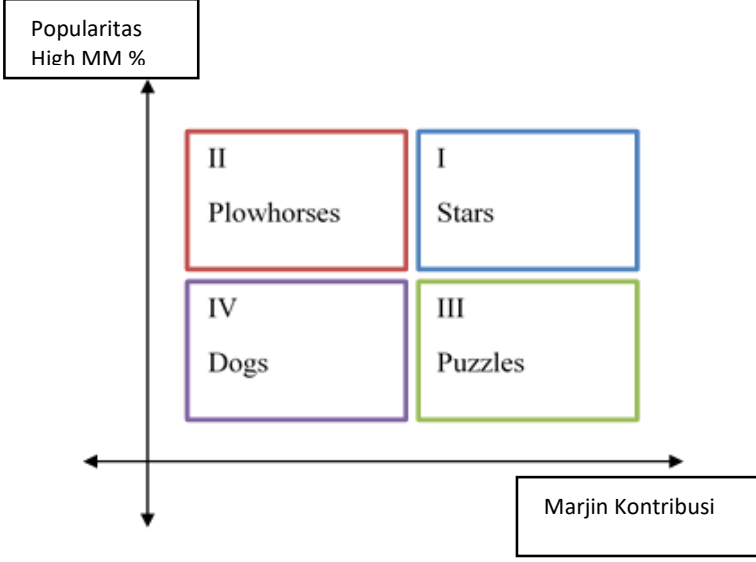

Sumber: Jagles dan Ralston (2007:257) 


\section{METODE PENELITIAN}

\section{Jenis dan Metode Penelitian}

Berdasarkan tujuan yang akan dicapai dalam penelitian ini, metode penelitian yang digunakan dalam penelitian ini yaitu metode deskriptif. Dalam bukunya yang berjudul Metode Penelitian Administrasi, Sugiyono (2009:11) mengatakan bahwa: "Penelitian deskriptif adalah penelitian yang dilakukan untuk mengetahui nilai variabel mandiri, baik satu variabel atau lebih (independen) tanpa membuat perbandingan, atau menghubungkan antara variabel satu dengan variabel lain". Metode ini penulis gunakan karena variabel yang ada adalah variabel mandiri dan dilakukan pada masa kini. Penelitian deskriptif tidak dimaksudkan untuk menguji hipotesis tertentu, tetapi hanya menggambarkan "apa adanya " tentang suatu variabel, gejala dan keadaan ".

\section{Teknik Pengumpulan Data}

\section{a. Observasi Langsung}

Penulis melakukan pengamatan secara langsung terhadap objek yang penulis teliti. Menurut Samsudin (2013:37) dalam buku Metodelogi Penelitian, observasi langsung adalah cara pengumpulan data dengan menggunakan indra penglihatan tanpa menggunakan alat standar lain. Dalam melakukan penelitian di Kambing Soon Bandung penulis melakukan pengamatan secara langsung terhadap objek yang diteliti.

b. Wawancara

Penulis melakukan wawancara dengan Manager Kambing Soon Bandung untuk memperoleh informasi yang dibutuhkan oleh penulis dalam melakukan penulisan. Menurut Sugiyono (2013:231) yaitu "Wawancara merupakan pertemuan dua orang untuk bertukar informasi dan ide melalui tanya jawab, sehingga dapat dikontruksikan makna dalam suatu topik tertentu". Informasi yang dibutuhkan penulis diantaranya adalah sejarah berdirinya Kambing Soon Bandung, struktur organisasi, jumlah karyawan, kapasitas tempat duduk, fasilitas, serta cara pengevaluasian menu yang dilakukan pihak Kambing Soon Bandung.

\section{c. Studi Kepustakaan}

Menurut Arikunto (2006:166) "Studi pustaka adalah metode pengumpulan data dengan cara mencari informasi melalui buku-buku, koran, majalah, dan literatur lainnya". Dalam penulisan ini, pengumpulan data dilakukan dengan membaca dan mempelajari buku-buku yang berkaitan dengan evaluasi menu sebagai landasan teori.

\section{d. Studi Dokumentasi}

Studi dokumentasi merupakan catatan peristiwa yang sudah berlalu. Nawawi (2005:95) mengungkapkan: "Teknik studi dokumentasi adalah cara pengumpulan data yang dilakukan dengan kategorisasi dan klasifikasi bahan-bahan tertulis yang berhubunngan dengan masalah penelitian, baik dari sumber dokumen maupun bukubuku, koran, atau majalah". Dalam penelitian ini mengambil data berupa foto-foto dari lokus penelitian.

\section{Metode Analisis Data}

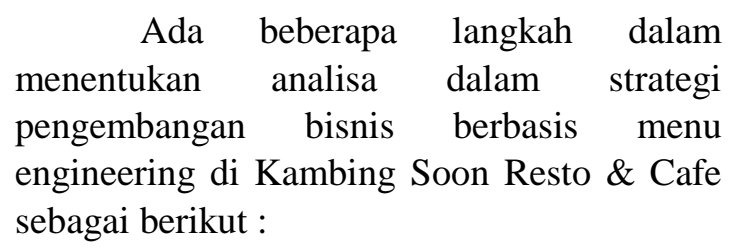

Indeks Popularitas Menu

Evaluasi menu dapat dilakukan dengan cara menganalisa tingkat kepopuleran dan tingkat keuntungan yang didapat oleh perusahaan dari setiap produk yang dijual. Setelah mengetahui jumlah penjualan dari sales history, kita akan menghitung popularity index yang diharapkan dari masing-masing menu. Indeks popularitas dapat dihitung dengan membagi jumlah porsi yang terjual dari satu jenis menu dengan total porsi yang terjual dari semua menu.

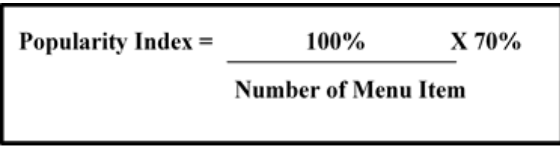

Mепи Mix 
Menu mix percentage adalah persentase jumlah penjualan dari setiap menu, yang didapat dengan cara membagi jumlah porsi yang terjual dari masing-masing menu dengan total dari seluruh menu yang terjual kemudian dikali dengan 100.

Menu Mix $\%=\frac{\text { Number of Item Sold }}{\text { Total Number of Item Sold }} \quad$ X 100\%

Marjin Kontribusi

Marjin kontribusi adalah data yang digunakan untuk mengetahui tingkat profitabilitas suatu menu. Yang dapat diartikan $\mathrm{CM}$ dihitung dengan mengurangi biaya makanan dari total pendapatan.

Contribution Margin = Selling Price - Food Cost per-portion

\section{Average Contribution Margin}

Rata-rata margin kontribusi didapat dengan membagi total margin kontribusi dengan total menu yang terjual. Sehingga, dapat dirumuskan sebagai berikut:

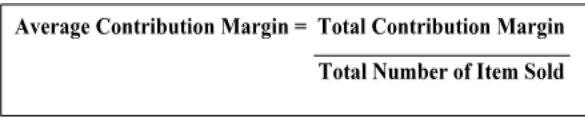

Hasil dari Item Contribution Margin akan dibandingkan dengan Average Contribution Margin untuk melihat tinggi atau rendahnya tingkat kontribusi suatu item menu.

\section{Klasifikasi Menu}

Menu dapat dievaluasikan dengan menganalisis popularitas dan kemampuan masing - masing jenis makanan dan minuman pada sebuah menu dalam memberikan kontribusi keuntungan. Setiap menu diklasifikasikan dalam empat kategori, yaitu Stars, Plowhorses, Puzzles, dan Dogs.

\section{HASIL DAN PEMBAHASAN}

\section{Tinjauan Mengenai Indeks Popularitas Menu Di Kambing Soon Resto \& Café Bandung}

Untuk mengetahui sejauh mana suatu menu itu populer, dapat dilakukan dengan mencatat dan menganalisa jumlah penjualan dari menu yang ditawarkan. Sales history adalah sebuah format untuk merekapitulasi penjualan selama suatu periode

Berikut ini adalah data jumlah penjualan makanan (sales history) di Kambing Soon Resto \& Café Bandung periode Maret 2017 - Agustus 2017:

Tabel 2

Sales History Produk Makanan Di Kambing Soon Resto \& Café Bandung

Periode Maret - Agustus 2017

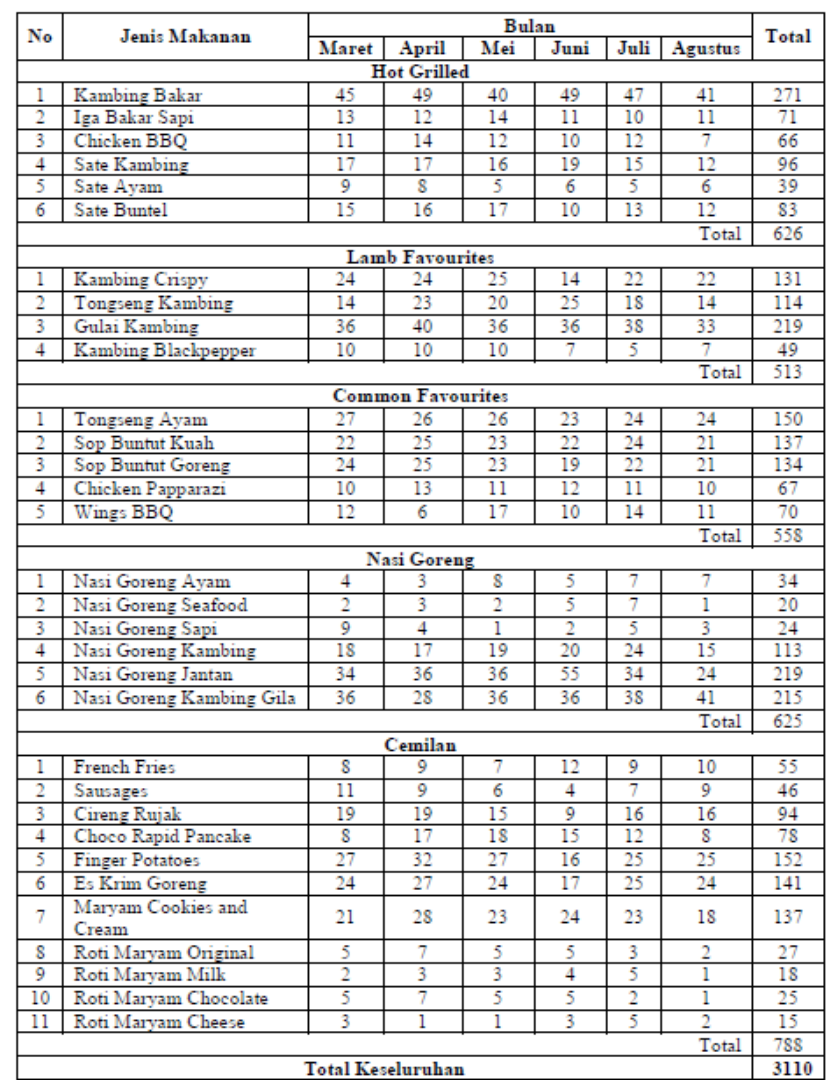

Tingkat popularitas tersebut dapat dicari dengan perhitungan membagi $100 \%$ dengan total menu yang ada pada setiap kategori, lalu hasil dari perhitungan tersebut dikalikan dengan $70 \%$, yang akan didapatkan 
index popularity kategori tersebut. Index popularity ini yang menjadi batas untuk menentukan apakah menu dalam kategori tersebut populer atau kurang populer. Apabila hasil perhitungan menu mix \% suatu menu dalam kategori tersebut melebihi index popularity-nya, menu tersebut dapat digolongkan populer, namun jika lebih rendah maka menu tersebut dikategorikan kurang populer.

Berdasarkan rumus diatas, maka indeks popularitas dari menu makanan dapat dicari, seperti berikut:

Tabel 2

Indeks Popularitas Menu Di Kambing Soon Resto \& Café Bandung

Periode Maret - Agustus 2017

\begin{tabular}{|c|l|c|c|}
\hline No & \multicolumn{1}{|c|}{$\begin{array}{c}\text { Kategori } \\
\text { Menu }\end{array}$} & $\begin{array}{c}\text { Jumlah } \\
\text { Item }\end{array}$ & $\begin{array}{c}\text { Indeks } \\
\text { Popularitas } \\
(\boldsymbol{\%})\end{array}$ \\
\hline 1 & Hot Grilled & 6 & 11.67 \\
\hline 2 & Lamb Favorites & 4 & 17.50 \\
\hline 3 & $\begin{array}{l}\text { Common } \\
\text { Favorites }\end{array}$ & 5 & 14.00 \\
\hline 4 & Nasi Goreng & 6 & 11.67 \\
\hline 5 & Cemilan & 11 & 6.36 \\
\hline
\end{tabular}

Dari hasil pengolahan data yang dilakukan penulis, berikut adalah tabel perhitungan tingkat popularitas setiap menu makanan di Kambing Soon Resto \& Café Bandung periode Maret - Agustus 2017:

Tabel 3

Kategori Menu Mix "Hot Grilled"

Periode Maret - Agustus 2017

\begin{tabular}{|c|c|c|c|c|}
\hline No & Menu Item Name & $\begin{array}{c}\text { Number } \\
\text { Sold }\end{array}$ & $\begin{array}{c}\text { Menu Mix } \\
(\%)\end{array}$ & $\begin{array}{c}\text { MM } \\
\text { Category }\end{array}$ \\
\hline & Hot Grilled & & & \\
\hline 1 & Kambing Bakar & 271 & 43.29 & High \\
\hline 2 & Iga Bakar Sapi & 71 & 11.34 & Low \\
\hline 3 & Chicken BBQ & 66 & 10.54 & Low \\
\hline 4 & Sate Kambing & 96 & 15.34 & High \\
\hline 5 & Sate Ayam & 39 & 6.23 & Low \\
\hline \multirow[t]{3}{*}{6} & Sate Buntel & 83 & 13.26 & High \\
\hline & Total & 626 & & \\
\hline & \multicolumn{2}{|c|}{ Popularity Index } & 11.67 & \\
\hline
\end{tabular}

Tabel 4

Kategori Menu Mix "Lamb Favourite" Periode Maret - Agustus 2017

\begin{tabular}{|c|c|c|c|c|}
\hline No & $\begin{array}{c}\text { Menu Item } \\
\text { Name }\end{array}$ & $\begin{array}{c}\text { Number } \\
\text { Sold }\end{array}$ & $\begin{array}{c}\text { Menu Mix } \\
(\%)\end{array}$ & $\begin{array}{c}\text { MM } \\
\text { Category }\end{array}$ \\
\hline & Lamb Favorites & & & \\
\hline 1 & Kambing Crispy & 131 & 25.54 & High \\
\hline 2 & $\begin{array}{l}\text { Tongseng } \\
\text { Kambing }\end{array}$ & 114 & 22.22 & High \\
\hline 3 & Gulai Kambing & 219 & 42.69 & High \\
\hline 4 & $\begin{array}{l}\text { Kambing } \\
\text { Blackpepper }\end{array}$ & 49 & 9.55 & Low \\
\hline & Total & 513 & & \\
\hline & \multicolumn{2}{|c|}{ Popularity Index } & 17.5 & \\
\hline
\end{tabular}

Tabel 5

Kategori Menu Mix "Common Favourite" Periode Maret - Agustus 2017

\begin{tabular}{|c|c|c|c|c|}
\hline No & $\begin{array}{l}\text { Menu Item } \\
\text { Name }\end{array}$ & $\begin{array}{l}\text { Number } \\
\text { Sold }\end{array}$ & $\begin{array}{c}\text { Menu } \\
\text { Mix } \\
(\%)\end{array}$ & $\begin{array}{c}\text { MM } \\
\text { Category }\end{array}$ \\
\hline & $\begin{array}{c}\text { Common } \\
\text { Favorites } \\
\end{array}$ & & & \\
\hline 1 & $\begin{array}{l}\text { Tongseng } \\
\text { Ayam }\end{array}$ & 150 & 26.88 & High \\
\hline 2 & $\begin{array}{l}\text { Sop Buntut } \\
\text { Kuah }\end{array}$ & 137 & 24.55 & High \\
\hline 3 & $\begin{array}{l}\text { Sop Buntut } \\
\text { Goreng }\end{array}$ & 134 & 24.01 & High \\
\hline 4 & $\begin{array}{l}\text { Chicken } \\
\text { Papparazi }\end{array}$ & 67 & 12.01 & Low \\
\hline 5 & Wings BBQ & 70 & 12.54 & Low \\
\hline & Total & 558 & & \\
\hline & \multicolumn{2}{|c|}{ Popularity Index } & 14 & \\
\hline
\end{tabular}

Tabel 6

Kategori Mепи Mix "Nasi Goreng" Periode Maret - Agustus 2017

\begin{tabular}{|c|c|c|c|c|}
\hline No & $\begin{array}{c}\text { Menu Item } \\
\text { Name }\end{array}$ & $\begin{array}{c}\text { Number } \\
\text { Sold }\end{array}$ & $\begin{array}{c}\text { Menu } \\
\text { Mix }(\%) \\
\end{array}$ & $\begin{array}{c}\text { MM } \\
\text { Category } \\
\end{array}$ \\
\hline & Nasi Goreng & & & \\
\hline 1 & $\begin{array}{l}\text { Nasi Goreng } \\
\text { Ayam }\end{array}$ & 34 & 5.44 & Low \\
\hline 2 & $\begin{array}{l}\text { Nasi Goreng } \\
\text { Seafood }\end{array}$ & 20 & 3.2 & Low \\
\hline 3 & $\begin{array}{l}\text { Nasi Goreng } \\
\text { Sapi }\end{array}$ & 24 & 3.84 & Low \\
\hline 4 & $\begin{array}{l}\text { Nasi Goreng } \\
\text { Kambing }\end{array}$ & 113 & 18.08 & High \\
\hline 5 & $\begin{array}{l}\text { Nasi Goreng } \\
\text { Jantan }\end{array}$ & 219 & 35.04 & High \\
\hline 6 & $\begin{array}{l}\text { Nasi Goreng } \\
\text { Kambing } \\
\text { Gila }\end{array}$ & 215 & 34.4 & High \\
\hline & Total & 625 & & \\
\hline & $\begin{array}{l}\text { Popularity } \\
\text { Index }\end{array}$ & & 11.67 & \\
\hline
\end{tabular}


Kategori Menu Mix “Cemilan" Periode Maret - Agustus 2017

\begin{tabular}{|c|c|c|c|c|}
\hline No & $\begin{array}{c}\text { Menu Item } \\
\text { Name }\end{array}$ & $\begin{array}{c}\text { Number } \\
\text { Sold }\end{array}$ & $\begin{array}{c}\text { Menu Mix } \\
(\%)\end{array}$ & $\begin{array}{c}\text { MM } \\
\text { Category }\end{array}$ \\
\hline & Cemilan & & & \\
\hline 1 & French Fries & 55 & 6.98 & High \\
\hline 2 & Sausages & 46 & 5.84 & Low \\
\hline 3 & Cireng Rujak & 94 & 11.93 & High \\
\hline 4 & $\begin{array}{l}\text { Choco Rapid } \\
\text { Pancake } \\
\end{array}$ & 78 & 9.90 & High \\
\hline 5 & Finger Potatoes & 152 & 19.29 & High \\
\hline 6 & $\begin{array}{l}\text { Es Krim } \\
\text { Goreng }\end{array}$ & 141 & 17.89 & High \\
\hline 7 & $\begin{array}{l}\text { Maryam } \\
\text { Cookies and } \\
\text { Cream }\end{array}$ & 137 & 17.39 & High \\
\hline 8 & $\begin{array}{l}\text { Roti Maryam } \\
\text { Original }\end{array}$ & 27 & 3.43 & Low \\
\hline 9 & $\begin{array}{l}\text { Roti Maryam } \\
\text { Milk }\end{array}$ & 18 & 2.28 & Low \\
\hline 10 & $\begin{array}{l}\text { Roti Maryam } \\
\text { Chocolate }\end{array}$ & 25 & 3.17 & Low \\
\hline 11 & $\begin{array}{l}\text { Roti Maryam } \\
\text { Cheese }\end{array}$ & 15 & 1.90 & Low \\
\hline & Total & 788 & & \\
\hline & \multicolumn{2}{|c|}{ Popularity Index } & 6.36 & \\
\hline
\end{tabular}

Sumber: Hasil Olahan Penulis profitabilitas suatu menu. Dalam marjin kontribusi ada dua faktor penentu yaitu food cost dan selling price Setelah menghitung contribution margin dari masing-masing menu, selanjutnya adalah menghitung average contribution margin dari setiap kategori menu.

Jika kontribusi marjin suatu item lebih rendah dari kontribusi marjin rata-rata, maka dapat dicatat atau ditandai dengan $\mathrm{L}$ sebagai rendah (low), sebaliknya jika kontribusi marjin suatu item lebih tinggi dari kontribusi marjin rata-rata, maka dapat ditandai dengan $\mathrm{H}$ sebagai tinggi (high).

Berikut ini merupakan data hasil olahan penulis mengenai contribution margin dari menu makanan di Kambing Soon Resto \& Café Bandung pada periode Maret Agustus 2017:

\section{Tinjauan Mengenai Marjin Kontribusi Di Kambing Soon Resto \& Café Bandung}

Marjin kontribusi adalah data yang digunakan untuk mengetahui tingkat

Tabel 8

Marjin Kontribusi Di Kambing "Hot Grilled"

Periode Maret - Agustus 2017

\begin{tabular}{|c|c|c|c|c|c|c|c|c|c|}
\hline No & $\begin{array}{l}\text { Menu Item } \\
\text { Name }\end{array}$ & $\begin{array}{l}\text { Number } \\
\text { Sold } \\
\text { (MM) } \\
\end{array}$ & $\begin{array}{l}\text { Item Food } \\
\text { Cost (Rp) }\end{array}$ & $\begin{array}{c}\text { Item } \\
\text { Selling } \\
\text { Price (Rp) }\end{array}$ & $\begin{array}{c}\text { Item CM } \\
\text { (Rp) }\end{array}$ & $\begin{array}{c}\text { Menu Cost } \\
\text { (Rp) }\end{array}$ & $\begin{array}{l}\text { Menu Revenue } \\
\text { (Rp) }\end{array}$ & $\begin{array}{c}\text { Menu CM } \\
\text { (Rp) }\end{array}$ & $\begin{array}{c}\text { CM } \\
\text { Category }\end{array}$ \\
\hline & Hot Grilled & & & & & & & & \\
\hline 1 & Kambing Bakar & 271 & $\operatorname{Rp} 37,500$ & Rp 65,000 & $\mathrm{Rp} 27,500$ & Rp $10,162,500$ & Rp 17,615,000 & $\operatorname{Rp} 7,452,500$ & High \\
\hline 2 & Iga Bakar Sapi & 71 & Rp 31,667 & Rp 65,000 & Rp 33,333 & Rp 2,248,357 & $\mathrm{Rp} 4,615,000$ & $\operatorname{Rp} 2,366,643$ & High \\
\hline 3 & Chicken BBQ & 66 & $\operatorname{Rp} 20,000$ & Rp 50,000 & Rp 30,000 & Rp 1,320,000 & $\operatorname{Rp} 3,300,000$ & Rp 1,980,000 & High \\
\hline 4 & Sate Kambing & 96 & Rp 30,509 & Rp 50,000 & Rp 19,491 & Rp 2,928,864 & $\operatorname{Rp} 4,800,000$ & Rp 1,871,136 & Low \\
\hline 5 & Sate Ayam & 39 & Rp 17,592 & Rp 40,000 & $\mathrm{Rp} 22,408$ & $\operatorname{Rp} 686,088$ & Rp 1,560,000 & $\operatorname{Rp} 873,912$ & Low \\
\hline 6 & Sate Buntel & 83 & Rp 12,600 & Rp 30,000 & Rp 17,400 & Rp $1,045,800$ & Rp 2,490,000 & Rp $1,444,200$ & Low \\
\hline & Total & 626 & & & & Rp 18,391,609 & Rp 34,380,000 & Rp 15,988,391 & \\
\hline & Average CM & & & & & & & $\operatorname{Rp} 25,540.56$ & \\
\hline
\end{tabular}

Tabel 9

Marjin Kontribusi "Lamb Favourite"

Periode Maret - Agustus 2017

\begin{tabular}{|c|c|c|c|c|c|c|c|c|c|}
\hline No & $\begin{array}{c}\text { Menu Item } \\
\text { Name }\end{array}$ & $\begin{array}{c}\text { Number } \\
\text { Sold }\end{array}$ & $\begin{array}{l}\text { Item Food } \\
\text { Cost (Rp) }\end{array}$ & $\begin{array}{c}\text { Item } \\
\text { Selling }\end{array}$ & $\begin{array}{c}\text { Item CM } \\
(\mathbf{R p})\end{array}$ & $\begin{array}{c}\text { Menu Cost } \\
(\mathbf{R p})\end{array}$ & $\begin{array}{c}\text { Menu Revenue } \\
\text { (Rp) }\end{array}$ & $\begin{array}{c}\text { Menu CM } \\
(\mathbf{R p})\end{array}$ & $\begin{array}{c}\text { CM } \\
\text { Category }\end{array}$ \\
\hline
\end{tabular}




\begin{tabular}{|c|c|c|c|c|c|c|c|c|c|}
\hline & & (MM) & & Price (Rp) & & & & & \\
\hline & Lamb Favorites & & & & & & & & \\
\hline 1 & Kambing Crispy & 131 & Rp 15,508 & $\operatorname{Rp} 35,000$ & Rp 19,492 & $\operatorname{Rp} 2,031,548$ & $\operatorname{Rp} 4,585,000$ & Rp 2,553,452 & High \\
\hline 2 & $\begin{array}{l}\text { Tongseng } \\
\text { Kambing } \\
\end{array}$ & 114 & Rp 14,108 & $\operatorname{Rp} 32,000$ & Rp 17,892 & Rp 1,608,312 & Rp 3,648,000 & Rp 2,039,688 & Low \\
\hline 3 & Gulai Kambing & 219 & $\operatorname{Rp} 27,319$ & $\operatorname{Rp} 45,000$ & Rp 17,681 & Rp 5,982,861 & Rp 9,855,000 & Rp $3,872,139$ & Low \\
\hline 4 & $\begin{array}{l}\text { Kambing } \\
\text { Blackpepper }\end{array}$ & 49 & $\operatorname{Rp} 28,427$ & $\operatorname{Rp} 45,000$ & Rp 16,573 & Rp 1,392,923 & $\operatorname{Rp} 2,205,000$ & Rp 812,077 & Low \\
\hline & Total & 513 & & & & Rp 11,015,644 & Rp 20,293,000 & Rp 9,277,356 & \\
\hline & Average CM & & & & & & & Rp 18,084.51 & \\
\hline
\end{tabular}

Tabel 10

Marjin Kontribusi Di Kambing "Common Favourite”

Periode Maret - Agustus 2017

\begin{tabular}{|c|c|c|c|c|c|c|c|c|c|}
\hline No & Menu Item Name & $\begin{array}{l}\text { Number } \\
\text { Sold } \\
\text { (MM) }\end{array}$ & $\begin{array}{l}\text { Item Food } \\
\text { Cost (Rp) }\end{array}$ & $\begin{array}{l}\text { Item Selling } \\
\text { Price (Rp) }\end{array}$ & $\begin{array}{c}\text { Item CM } \\
\text { (Rp) }\end{array}$ & $\begin{array}{l}\text { Menu Cost } \\
\text { (Rp) }\end{array}$ & $\begin{array}{c}\text { Menu Revenue } \\
\text { (Rp) }\end{array}$ & $\begin{array}{c}\text { Menu CM } \\
\quad(\mathbf{R p})\end{array}$ & $\begin{array}{c}\text { CM } \\
\text { Category }\end{array}$ \\
\hline & $\begin{array}{l}\text { Common } \\
\text { Favorites }\end{array}$ & & & & & & & & \\
\hline 1 & Tongseng Ayam & 150 & Rp 9,000 & $\operatorname{Rp} 32,000$ & Rp 23,000 & Rp $1,350,000$ & $\operatorname{Rp} \quad 4,800,000$ & Rp $3,450,000$ & High \\
\hline 2 & Sop Buntut Kuah & 137 & $\operatorname{Rp} 42,774$ & $\mathrm{Rp} 50,000$ & Rp 7,226 & Rp $5,860,038$ & $\operatorname{Rp} \quad 6,850,000$ & Rp $\quad 989,962$ & Low \\
\hline 3 & Sop Buntut Goreng & 134 & $\operatorname{Rp} 44,980$ & $\mathrm{Rp} 55,000$ & Rp 10,020 & Rp $6,027,320$ & $\mathrm{Rp} \quad 7,370,000$ & $\operatorname{Rp} 1,342,680$ & Low \\
\hline 4 & Chicken Papparazi & 67 & $\operatorname{Rp} 10,745$ & Rp 30,000 & Rp 19,255 & Rp $\quad 719,915$ & $\mathrm{Rp} \quad 2,010,000$ & Rp $1,290,085$ & High \\
\hline 5 & Wings BBQ & 70 & Rp 8,574 & $\operatorname{Rp} 25,000$ & Rp 16,426 & $\mathrm{Rp} \quad 600,180$ & $\mathrm{Rp} \quad 1,750,000$ & Rp $1,149,820$ & High \\
\hline & Total & 558 & & & & $\operatorname{Rp} 14,557,453$ & Rp $22,780,000$ & Rp 8,222,547 & \\
\hline & Average CM & & & & & & & 14,736 & \\
\hline
\end{tabular}

Tabel 11

Marjin Kontribusi "Nasi Goreng"

Periode Maret - Agustus 2017

\begin{tabular}{|c|c|c|c|c|c|c|c|c|c|}
\hline No & $\begin{array}{l}\text { Menu Item } \\
\text { Name }\end{array}$ & $\begin{array}{c}\text { Number } \\
\text { Sold } \\
(\mathrm{MM}) \\
\end{array}$ & $\begin{array}{l}\text { Item Food } \\
\text { Cost (Rp) }\end{array}$ & $\begin{array}{c}\text { Item } \\
\text { Selling } \\
\text { Price (Rp) }\end{array}$ & $\begin{array}{c}\text { Item CM } \\
\text { (Rp) }\end{array}$ & $\underset{\text { (Rp) }}{\text { Menu Cost }}$ & $\begin{array}{l}\text { Menu Revenue } \\
\text { (Rp) }\end{array}$ & $\underset{(\text { Rp) }}{\text { Menu CM }}$ & $\begin{array}{c}\text { CM } \\
\text { Category }\end{array}$ \\
\hline & Nasi Goreng & & & & & & & & \\
\hline 1 & $\begin{array}{l}\text { Nasi Goreng } \\
\text { Ayam }\end{array}$ & 34 & Rp 9,129 & Rp 25,000 & Rp 15,871 & Rp 310,386 & $\operatorname{Rp} 850,000$ & Rp 539,614 & Low \\
\hline 2 & $\begin{array}{l}\text { Nasi Goreng } \\
\text { Seafood }\end{array}$ & 20 & $\operatorname{Rp} 11,300$ & Rp 25,000 & $\operatorname{Rp} 13,700$ & Rp 226,000 & Rp 500,000 & Rp 274,000 & Low \\
\hline 3 & $\begin{array}{l}\text { Nasi Goreng } \\
\text { Sapi }\end{array}$ & 24 & Rp 12,903 & $\operatorname{Rp} 25,000$ & Rp 12,097 & Rp 309,672 & Rp 600,000 & Rp 290,328 & Low \\
\hline 4 & $\begin{array}{l}\text { Nasi Goreng } \\
\text { Kambing }\end{array}$ & 113 & Rp 11,757 & $\operatorname{Rp} 30,000$ & Rp 18,243 & Rp 1,328,541 & $\mathrm{Rp} 3,390,000$ & $\mathrm{Rp} 2,061,459$ & Low \\
\hline 5 & $\begin{array}{l}\text { Nasi Goreng } \\
\text { Jantan }\end{array}$ & 219 & $\operatorname{Rp} 11,500$ & $\operatorname{Rp} 30,000$ & $\mathrm{Rp} 18,500$ & $\mathrm{Rp} 2,518,500$ & $\operatorname{Rp} 6,570,000$ & $\mathrm{Rp} 4,051,500$ & Low \\
\hline \multirow[t]{3}{*}{6} & $\begin{array}{l}\text { Nasi Goreng } \\
\text { Kambing Gila } \\
\end{array}$ & 215 & $\operatorname{Rp} 23,381$ & $\operatorname{Rp} 65,000$ & $\operatorname{Rp} 41,619$ & Rp 5,026,915 & Rp $13,975,000$ & Rp 8,948,085 & High \\
\hline & Total & 625 & & & & Rp 9,720,014 & Rp $25,885,000$ & Rp $16,164,986$ & \\
\hline & Average CM & & & & & & & $\mathrm{Rp} \quad 25,864$ & \\
\hline
\end{tabular}


Periode Maret - Agustus 2017

\begin{tabular}{|c|c|c|c|c|c|c|c|c|c|}
\hline No & $\begin{array}{c}\text { Menu Item } \\
\text { Name }\end{array}$ & $\begin{array}{l}\text { Number } \\
\text { Sold } \\
\text { (MM) }\end{array}$ & $\begin{array}{c}\text { Item Food } \\
\text { Cost (Rp) }\end{array}$ & $\begin{array}{c}\text { Item Selling } \\
\text { Price (Rp) }\end{array}$ & $\begin{array}{c}\text { Item CM } \\
\quad(\mathbf{R p})\end{array}$ & $\begin{array}{c}\text { Menu Cost } \\
\text { (Rp) }\end{array}$ & $\begin{array}{c}\text { Menu Revenue } \\
\text { (Rp) }\end{array}$ & $\begin{array}{c}\text { Menu CM } \\
\quad(\text { Rp) }\end{array}$ & $\begin{array}{c}\text { CM } \\
\text { Category }\end{array}$ \\
\hline & Cemilan & & & & & & & & \\
\hline 1 & French Fries & 55 & Rp 9,600 & Rp 28,000 & Rp 18,400 & 528,000 & $\operatorname{Rp} \quad 1,375,000$ & $\mathrm{Rp} \quad 1,012,000$ & High \\
\hline 2 & Sausages & 46 & Rp 18,000 & Rp 25,000 & Rp 7,000 & 828,000 & $\mathrm{Rp} \quad 1,380,000$ & Rp $\quad 322,000$ & Low \\
\hline 3 & Cireng Rujak & 94 & Rp 10,000 & Rp 30,000 & Rp 20,000 & Rp 940,000 & $\mathrm{Rp} \quad 2,350,000$ & Rp $1,880,000$ & High \\
\hline 4 & $\begin{array}{l}\text { Choco Rapid } \\
\text { Pancake } \\
\end{array}$ & 78 & $\operatorname{Rp} 15,500$ & Rp 25,000 & Rp $\quad 9,500$ & Rp $1,209,000$ & $\operatorname{Rp} \quad 1,950,000$ & 741,000 & Low \\
\hline 5 & Finger Potatoes & 152 & Rp 7,440 & Rp 25,000 & Rp 17,560 & Rp $1,130,880$ & $\mathrm{Rp} \quad 3,496,000$ & $\mathrm{Rp} \quad 2,669,120$ & High \\
\hline 6 & $\begin{array}{l}\text { Es Krim } \\
\text { Goreng } \\
\end{array}$ & 141 & Rp 13,587 & Rp 23,000 & $\mathrm{Rp} \quad 9,413$ & $\mathrm{Rp} \quad 1,915,767$ & $\mathrm{Rp} \quad 2,820,000$ & Rp $1,327,233$ & Low \\
\hline 7 & $\begin{array}{l}\text { Maryam } \\
\text { Cookies and } \\
\text { Cream }\end{array}$ & 137 & Rp 6,780 & Rp 20,000 & $\operatorname{Rp} 13,220$ & 928,860 & $\mathrm{Rp} \quad 2,192,000$ & $\mathrm{Rp} \quad 1,811,140$ & Low \\
\hline 8 & $\begin{array}{l}\text { Roti Maryam } \\
\text { Original }\end{array}$ & 27 & $\mathrm{Rp} \quad 5,280$ & Rp 16,000 & $\operatorname{Rp} 10,720$ & 142,560 & 459,000 & 289,440 & Low \\
\hline 9 & $\begin{array}{l}\text { Roti Maryam } \\
\text { Milk }\end{array}$ & 18 & Rp 6,000 & Rp 17,000 & Rp 11,000 & 108,000 & 324,000 & 198,000 & Low \\
\hline 10 & $\begin{array}{l}\text { Roti Maryam } \\
\text { Chocolate }\end{array}$ & 25 & Rp 6,000 & Rp 18,000 & Rp 12,000 & 150,000 & 450,000 & 300,000 & Low \\
\hline 11 & $\begin{array}{l}\text { Roti Maryam } \\
\text { Cheese }\end{array}$ & 15 & Rp 7,992 & Rp 18,000 & Rp 10,008 & 119,880 & 270,000 & 150,120 & Low \\
\hline & Total & 788 & & & & Rp $8,000,947$ & Rp $17,066,000$ & Rp $10,700,053$ & \\
\hline & Average CM & & & & & & & $\mathrm{Rp} \quad 13,579$ & \\
\hline
\end{tabular}

Tinjauan Mengenai Klasifikasi Menu Di Kambing Soon Resto \& Café Bandung

Menu dapat dievaluasikan dengan menganalisis popularitas dan kemampuan masing - masing jenis makanan dan minuman pada sebuah menu dalam memberikan kontribusi keuntungan. Setelah sebuah menu telah diketahui tingkat popularitas dan profitabilitasnya, maka sebuah menu dapat dimasukkan ke dalam suatu lembar kerja yang disebut lembar kerja rekayasa menu atau menu engineering worksheet.

Berikut ini merupakan tabel hasil olahan data penulis berdasarkan menu engineering worksheet dan gambar menu classification dari kategori menu yang ada di Kambing Soon Resto \& Café Bandung untuk periode Maret-Agustus 2017.

Tabel 13

Menu Engineering Worksheet "Hot Grilled"

Periode Maret - Agustus 2017

\begin{tabular}{|c|c|c|c|c|c|c|c|c|c|c|c|c|}
\hline & $\mathbf{A}$ & B & C & D & $\mathbf{E}$ & $\mathbf{F}$ & G & H & $\mathbf{I}$ & $\mathbf{J}$ & $\mathbf{K}$ & $\mathbf{L}$ \\
\hline \multirow[t]{2}{*}{ No } & $\begin{array}{l}\text { Menu Item } \\
\text { Name }\end{array}$ & $\begin{array}{c}\text { Number } \\
\text { Sold } \\
\text { (MM) }\end{array}$ & $\begin{array}{c}\text { Menu } \\
\text { Mix (\%) }\end{array}$ & $\begin{array}{l}\text { Item Food } \\
\text { Cost (Rp) }\end{array}$ & $\begin{array}{c}\text { Item Selling } \\
\text { Price (Rp) }\end{array}$ & $\begin{array}{c}\text { Item CM } \\
\text { (Rp) }\end{array}$ & $\begin{array}{l}\text { Menu Cost } \\
\text { (Rp) }\end{array}$ & $\begin{array}{c}\text { Menu Revenue } \\
\text { (Rp) }\end{array}$ & $\begin{array}{c}\text { Menu CM } \\
\text { (Rp) }\end{array}$ & $\begin{array}{c}\text { CM } \\
\text { Category }\end{array}$ & $\begin{array}{c}\text { MM \% } \\
\text { Category }\end{array}$ & $\begin{array}{c}\text { Menu Item } \\
\text { Classification }\end{array}$ \\
\hline & Hot Grilled & & & & & & & & & & & \\
\hline 1 & $\begin{array}{l}\text { Kambing } \\
\text { Bakar }\end{array}$ & 271 & 43.29 & $\operatorname{Rp} 37,500$ & $\operatorname{Rp} 65,000$ & $\operatorname{Rp} 27,500$ & $\operatorname{Rp} 10,162,500$ & Rp $17,615,000$ & $\operatorname{Rp} 7,452,500$ & High & High & Stars \\
\hline 2 & $\begin{array}{l}\text { Iga Bakar } \\
\text { Sapi } \\
\end{array}$ & 71 & 11.34 & $\operatorname{Rp} 31,667$ & $\operatorname{Rp} 65,000$ & Rp 33,333 & Rp 2,248,357 & Rp 4,615,000 & Rp 2,366,643 & High & Low & Puzzles \\
\hline 3 & Chicken BBQ & 66 & 10.54 & $\operatorname{Rp} 20,000$ & $\operatorname{Rp} 50,000$ & $\operatorname{Rp} 30,000$ & Rp 1,320,000 & Rp 3,300,000 & Rp 1,980,000 & High & Low & Puzzles \\
\hline 4 & Sate Kambing & 96 & 15.34 & $\operatorname{Rp} 30,509$ & $\operatorname{Rp} 50,000$ & Rp 19,491 & $\operatorname{Rp} 2,928,864$ & $\mathrm{Rp} 4,800,000$ & Rp 1,871,136 & Low & High & Plowhorses \\
\hline 5 & Sate Ayam & 39 & 6.23 & Rp 17,592 & $\operatorname{Rp} 40,000$ & Rp 22,408 & Rp $\quad 686,088$ & Rp 1,560,000 & Rp $\quad 873,912$ & Low & Low & Dogs \\
\hline 6 & Sate Buntel & 83 & 13.26 & Rp 12,600 & Rp 30,000 & Rp 7,400 & Rp 1,045,800 & $\operatorname{Rp} 2,490,000$ & Rp 1,444,200 & Low & High & Plowhorses \\
\hline & Total & 626 & & & & & Rp 18,391,609 & Rp $34,380,000$ & Rp 15,988,391 & & & \\
\hline \multicolumn{3}{|c|}{ Average CM } & $\begin{array}{l}\mathrm{Rp} \\
25,540.56\end{array}$ & & & & & & & & & \\
\hline
\end{tabular}


Tabel 14

Menu Engineering Worksheet "Lamb Favourite"

Periode Maret - Agustus 2017

\begin{tabular}{|c|c|c|c|c|c|c|c|c|c|c|c|c|}
\hline & $\mathbf{A}$ & B & C & D & $\mathbf{E}$ & $\mathbf{F}$ & G & H & I & $\mathbf{J}$ & $\mathbf{K}$ & $\mathbf{L}$ \\
\hline No & $\begin{array}{l}\text { Menu Item } \\
\text { Name }\end{array}$ & $\begin{array}{c}\text { Number } \\
\text { Sold } \\
\text { (MM) }\end{array}$ & $\begin{array}{c}\text { Menu } \\
\text { Mix (\%) }\end{array}$ & $\begin{array}{l}\text { Item Food } \\
\text { Cost (Rp) }\end{array}$ & $\begin{array}{l}\text { Item Selling } \\
\text { Price (Rp) }\end{array}$ & $\begin{array}{c}\text { Item CM } \\
\text { (Rp) }\end{array}$ & $\begin{array}{l}\text { Menu Cost } \\
\text { (Rp) }\end{array}$ & $\begin{array}{c}\text { Menu Revenue } \\
\text { (Rp) }\end{array}$ & $\begin{array}{c}\text { Menu CM } \\
\text { (Rp) }\end{array}$ & $\begin{array}{c}\text { CM } \\
\text { Category }\end{array}$ & $\begin{array}{c}\text { MM \% } \\
\text { Category }\end{array}$ & $\begin{array}{l}\text { Menu Item } \\
\text { Classification }\end{array}$ \\
\hline & $\begin{array}{c}\text { Lamb } \\
\text { Favorites }\end{array}$ & & & & & & & & & & & \\
\hline 1 & $\begin{array}{l}\text { Kambing } \\
\text { Crispy }\end{array}$ & 131 & 25.54 & $\operatorname{Rp} 15,508$ & $\operatorname{Rp} 35,000$ & Rp 19,492 & Rp 2,031,548 & Rp 4,585,000 & $\operatorname{Rp} 2,553,452$ & High & High & Star \\
\hline 2 & $\begin{array}{l}\text { Tongseng } \\
\text { Kambing }\end{array}$ & 114 & 22.22 & Rp 14,108 & $\operatorname{Rp} 32,000$ & Rp 17,892 & Rp 1,608,312 & Rp 3,648,000 & Rp 2,039,688 & Low & High & Plowhorse \\
\hline 3 & $\begin{array}{l}\text { Gulai } \\
\text { Kambing }\end{array}$ & 219 & 42.69 & $\operatorname{Rp} 27,319$ & $\operatorname{Rp} 45,000$ & Rp 17,681 & Rp 5,982,861 & $\operatorname{Rp} 9,855,000$ & Rp 3,872,139 & Low & High & Plowhorse \\
\hline 4 & $\begin{array}{l}\text { Kambing } \\
\text { Blackpepper }\end{array}$ & 49 & 9.55 & $\operatorname{Rp} 28,427$ & $\operatorname{Rp} 45,000$ & $\operatorname{Rp} 16,573$ & Rp 1,392,923 & Rp 2,205,000 & Rp $\quad 812,077$ & Low & Low & Dog \\
\hline & Total & 513 & & & & & Rp 11,015,644 & $\operatorname{Rp} 20,293,000$ & Rp 9,277,356 & & & \\
\hline \multicolumn{3}{|c|}{ Average $\mathbf{C M}$} & $\begin{array}{c}\mathrm{Rp} \\
18,084.51\end{array}$ & & & & & & & & & \\
\hline \multicolumn{3}{|c|}{ Indeks Popularitas (\%) } & 17.5 & & & & & & & & & \\
\hline
\end{tabular}

Tabel 15

Menu Engineering Worksheet "Common Favourite"

Periode Maret - Agustus 2017

\begin{tabular}{|c|c|c|c|c|c|c|c|c|c|c|c|c|}
\hline & $\mathbf{A}$ & B & C & D & $\mathbf{E}$ & $\mathbf{F}$ & G & $\mathbf{H}$ & I & $\mathbf{J}$ & $\mathbf{K}$ & $\mathbf{L}$ \\
\hline \multirow[t]{2}{*}{ No } & $\begin{array}{l}\text { Menu } \\
\text { Item } \\
\text { Name } \\
\end{array}$ & $\begin{array}{l}\text { Number } \\
\text { Sold } \\
\text { (MM) } \\
\end{array}$ & $\begin{array}{c}\text { Menu } \\
\text { Mix (\%) }\end{array}$ & $\begin{array}{l}\text { Item Food } \\
\text { Cost (Rp) }\end{array}$ & $\begin{array}{l}\text { Item Selling } \\
\text { Price (Rp) }\end{array}$ & $\begin{array}{l}\text { Item CM } \\
\quad(\mathbf{R p})\end{array}$ & $\begin{array}{l}\text { Menu Cost } \\
\text { (Rp) }\end{array}$ & $\begin{array}{c}\text { Menu Revenue } \\
\text { (Rp) }\end{array}$ & $\begin{array}{c}\text { Menu CM } \\
\text { (Rp) }\end{array}$ & $\begin{array}{c}\text { CM } \\
\text { Category }\end{array}$ & $\begin{array}{c}\text { MM \% } \\
\text { Category }\end{array}$ & $\begin{array}{c}\text { Menu Item } \\
\text { Classification }\end{array}$ \\
\hline & \begin{tabular}{|l|} 
Common \\
Favorites \\
\end{tabular} & & & & & & & & & & & \\
\hline 1 & $\begin{array}{l}\text { Tongseng } \\
\text { Ayam }\end{array}$ & 150 & 26.88 & Rp 9,000 & $\operatorname{Rp} 32,000$ & $\operatorname{Rp} 23,000$ & Rp 1,350,000 & $\operatorname{Rp} 4,800,000$ & $\operatorname{Rp} 3,450,000$ & High & High & Star \\
\hline 2 & $\begin{array}{l}\text { Sop Buntut } \\
\text { Kuah }\end{array}$ & 137 & 24.55 & $\operatorname{Rp} 42,774$ & $\operatorname{Rp} 50,000$ & Rp 7,226 & Rp 5,860,038 & $\operatorname{Rp} 6,850,000$ & Rp $\quad 989,962$ & Low & High & Plowhorse \\
\hline 3 & $\begin{array}{l}\text { Sop Buntut } \\
\text { Goreng }\end{array}$ & 134 & 24.01 & $\operatorname{Rp} 44,980$ & $\operatorname{Rp} 55,000$ & Rp 10,020 & Rp 6,027,320 & $\operatorname{Rp} 7,370,000$ & Rp 1,342,680 & Low & High & Plowhorse \\
\hline 4 & $\begin{array}{l}\text { Chicken } \\
\text { Papparazi }\end{array}$ & 67 & 12.01 & Rp 10,745 & $\operatorname{Rp} 30,000$ & Rp 19,255 & Rp $\quad 719,915$ & $\operatorname{Rp} 2,010,000$ & Rp 1,290,085 & High & Low & Puzzle \\
\hline \multirow[t]{2}{*}{5} & $\begin{array}{l}\text { Wings } \\
\text { BBQ } \\
\end{array}$ & 70 & 12.54 & Rp 8,574 & Rp 25,000 & Rp 16,426 & $\mathrm{Rp} \quad 600,180$ & Rp $1,750,000$ & Rp $1,149,820$ & High & Low & Puzzle \\
\hline & Total & 558 & & & & & Rp $14,557,453$ & Rp 22,780,000 & $\operatorname{Rp} 8,222,547$ & & & \\
\hline \multicolumn{3}{|c|}{ Average CM } & $\begin{array}{l}\mathrm{Rp} \\
14,735.75 \\
\end{array}$ & & & & & & & & & \\
\hline \multicolumn{3}{|c|}{ Indeks Popularitas (\%) } & 14 & & & & & & & & & \\
\hline
\end{tabular}

Tabel 16

Menu Engineering Worksheet "Nasi Goreng"

Periode Maret - Agustus 2017

\begin{tabular}{|c|c|c|c|c|c|c|c|c|c|c|c|c|}
\hline & A & B & C & D & $\mathbf{E}$ & $\mathbf{F}$ & G & H & I & $\mathbf{J}$ & $\mathbf{K}$ & $\mathbf{L}$ \\
\hline No & $\begin{array}{l}\text { Menu Item } \\
\text { Name }\end{array}$ & $\begin{array}{l}\text { Number } \\
\text { Sold } \\
\text { (MM) }\end{array}$ & $\begin{array}{l}\text { Menu } \\
\text { Mix }(\%)\end{array}$ & $\begin{array}{l}\text { Item Food } \\
\text { Cost (Rp) }\end{array}$ & $\begin{array}{l}\text { Item Selling } \\
\text { Price (Rp) }\end{array}$ & $\begin{array}{c}\text { Item CM } \\
\text { (Rp) }\end{array}$ & $\begin{array}{l}\text { Menu Cost } \\
\text { (Rp) }\end{array}$ & $\begin{array}{c}\text { Menu Revenue } \\
\text { (Rp) }\end{array}$ & $\underset{\text { (Rp) }}{\text { Menu CM }}$ & $\begin{array}{c}\text { CM } \\
\text { Category }\end{array}$ & $\begin{array}{c}\text { MM \% } \\
\text { Category }\end{array}$ & $\begin{array}{l}\text { Menu Item } \\
\text { Classification }\end{array}$ \\
\hline & $\begin{array}{c}\text { Nasi } \\
\text { Goreng }\end{array}$ & & & & & & & & & & & \\
\hline
\end{tabular}




\begin{tabular}{|c|c|c|c|c|c|c|c|c|c|c|c|c|}
\hline 1 & $\begin{array}{l}\text { Nasi } \\
\text { Goreng } \\
\text { Ayam }\end{array}$ & 34 & 5.44 & Rp 9,129 & $\operatorname{Rp} 25,000$ & $\operatorname{Rp} 15,871$ & Rp 310,386 & 850,000 & 539,614 & Low & Low & Dog \\
\hline 2 & $\begin{array}{l}\text { Nasi } \\
\text { Goreng } \\
\text { Seafood }\end{array}$ & 20 & 3.20 & $\operatorname{Rp} 11,300$ & $\mathrm{Rp} 25,000$ & Rp 13,700 & Rp 226,000 & 500,000 & 274,000 & Low & Low & Dog \\
\hline 3 & $\begin{array}{l}\text { Nasi } \\
\text { Goreng } \\
\text { Sapi }\end{array}$ & 24 & 3.84 & $\operatorname{Rp} 12,903$ & $\mathrm{Rp} 25,000$ & Rp 12,097 & Rp 309,672 & $\mathrm{Rp} \quad 600,000$ & $\mathrm{Rp} \quad 290,328$ & Low & Low & Dog \\
\hline 4 & $\begin{array}{l}\text { Nasi } \\
\text { Goreng } \\
\text { Kambing }\end{array}$ & 113 & 18.08 & $\operatorname{Rp} 11,757$ & $\operatorname{Rp} 30,000$ & Rp 18,243 & Rp 1,328,541 & Rp 3,390,000 & Rp 2,061,459 & Low & High & Plowhorse \\
\hline 5 & $\begin{array}{l}\text { Nasi } \\
\text { Goreng } \\
\text { Jantan }\end{array}$ & 219 & 35.04 & $\operatorname{Rp} 11,500$ & $\operatorname{Rp} 30,000$ & $\mathrm{Rp} 18,500$ & $\operatorname{Rp} 2,518,500$ & Rp 6,570,000 & $\mathrm{Rp} 4,051,500$ & Low & High & Plowhorse \\
\hline 6 & $\begin{array}{l}\text { Nasi } \\
\text { Goreng } \\
\text { Kambing } \\
\text { Gila } \\
\end{array}$ & 215 & 34.40 & $\operatorname{Rp} 23,381$ & $\operatorname{Rp} 65,000$ & $\operatorname{Rp} 41,619$ & $\operatorname{Rp} 5,026,915$ & $\operatorname{Rp} 13,975,000$ & Rp 8,948,085 & High & High & Star \\
\hline & Total & 625 & & & & & Rp 9,720,014 & $\operatorname{Rp} 25,885,000$ & Rp $16,164,986$ & & & \\
\hline \multicolumn{3}{|c|}{ Average CM } & $\begin{array}{l}\mathrm{Rp} \\
25,863.98\end{array}$ & & & & & & & & & \\
\hline \multicolumn{3}{|c|}{ Indeks Popularitas (\%) } & 11.67 & & & & & & & & & \\
\hline
\end{tabular}

Tabel 17

Menu Engineering Worksheet "Cemilan"

Periode Maret - Agustus 2017

\begin{tabular}{|c|c|c|c|c|c|c|c|c|c|c|c|c|}
\hline & $\mathbf{A}$ & B & $\mathrm{C}$ & D & $\mathbf{E}$ & $\mathbf{F}$ & G & $\mathbf{H}$ & I & $\mathbf{J}$ & $\mathbf{K}$ & $\mathbf{L}$ \\
\hline No & $\begin{array}{l}\text { Menu } \\
\text { Item } \\
\text { Name } \\
\end{array}$ & $\begin{array}{c}\text { Number } \\
\text { Sold } \\
\text { (MM) } \\
\end{array}$ & $\begin{array}{c}\text { Menu } \\
\operatorname{Mix}(\%)\end{array}$ & $\begin{array}{l}\text { Item Food } \\
\text { Cost (Rp) }\end{array}$ & $\begin{array}{l}\text { Item Selling } \\
\text { Price (Rp) }\end{array}$ & $\begin{array}{c}\text { Item CM } \\
\text { (Rp) }\end{array}$ & $\begin{array}{l}\text { Menu Cost } \\
\text { (Rp) }\end{array}$ & $\begin{array}{l}\text { Menu Revenue } \\
\text { (Rp) }\end{array}$ & $\begin{array}{l}\text { Menu CM } \\
\text { (Rp) }\end{array}$ & $\begin{array}{c}\text { CM } \\
\text { Category }\end{array}$ & $\begin{array}{c}\text { MM \% } \\
\text { Category }\end{array}$ & $\begin{array}{l}\text { Menu Item } \\
\text { Classification }\end{array}$ \\
\hline & Cemilan & & & & & & & & & & & \\
\hline 1 & $\begin{array}{l}\text { French } \\
\text { Fries }\end{array}$ & 55 & 6.98 & Rp 9,600 & $\operatorname{Rp} 28,000$ & $\operatorname{Rp} 18,400$ & $\operatorname{Rp} 528,000$ & Rp 1,375,000 & Rp $1,012,000$ & High & High & Star \\
\hline 2 & Sausages & 46 & 5.84 & Rp 18,000 & $\mathrm{Rp} 25,000$ & Rp 7,000 & Rp 828,000 & Rp 1,380,000 & $\mathrm{Rp} \quad 322,000$ & Low & Low & Dog \\
\hline 3 & $\begin{array}{l}\text { Cireng } \\
\text { Rujak } \\
\end{array}$ & 94 & 11.93 & Rp 10,000 & Rp 30,000 & $\operatorname{Rp} 20,000$ & $\operatorname{Rp} 940,000$ & Rp 2,350,000 & Rp $1,880,000$ & High & High & Star \\
\hline 4 & $\begin{array}{l}\text { Choco } \\
\text { Rapid } \\
\text { Pancake } \\
\end{array}$ & 78 & 9.90 & $\operatorname{Rp} 15,500$ & $\operatorname{Rp} 25,000$ & Rp 9,500 & Rp $1,209,000$ & Rp $1,950,000$ & Rp $\quad 741,000$ & Low & High & Plowhorse \\
\hline 5 & $\begin{array}{l}\text { Finger } \\
\text { Potatoes } \\
\end{array}$ & 152 & 19.29 & Rp 7,440 & $\operatorname{Rp} 25,000$ & $\operatorname{Rp} 17,560$ & Rp $1,130,880$ & Rp 3,496,000 & $\operatorname{Rp} 2,669,120$ & High & High & Star \\
\hline 6 & $\begin{array}{l}\text { Es Krim } \\
\text { Goreng }\end{array}$ & 141 & 17.89 & Rp 13,587 & $\operatorname{Rp} 23,000$ & $\mathrm{Rp} \quad 9,413$ & Rp 1,915,767 & $\operatorname{Rp} 2,820,000$ & Rp 1,327,233 & Low & High & Plowhorse \\
\hline 7 & $\begin{array}{l}\text { Maryam } \\
\text { Cookies } \\
\text { and } \\
\text { Cream }\end{array}$ & 137 & 17.39 & Rp $\quad 6,780$ & $\operatorname{Rp} 20,000$ & Rp 13,220 & Rp $\quad 928,860$ & $\operatorname{Rp} 2,192,000$ & $\operatorname{Rp} 1,811,140$ & Low & High & Plowhorse \\
\hline 8 & $\begin{array}{l}\text { Roti } \\
\text { Maryam } \\
\text { Original } \\
\end{array}$ & 27 & 3.43 & Rp 5,280 & Rp 16,000 & Rp 10,720 & Rp $\quad 142,560$ & Rp $\quad 459,000$ & Rp $\quad 289,440$ & Low & Low & Dog \\
\hline 9 & $\begin{array}{l}\text { Roti } \\
\text { Maryam } \\
\text { Milk } \\
\end{array}$ & 18 & 2.28 & $\operatorname{Rp} \quad 6,000$ & Rp 17,000 & $\operatorname{Rp} 11,000$ & Rp $\quad 108,000$ & $\operatorname{Rp} \quad 324,000$ & $\operatorname{Rp} \quad 198,000$ & Low & Low & Dog \\
\hline 10 & $\begin{array}{l}\text { Roti } \\
\text { Maryam } \\
\text { Chocolate }\end{array}$ & 25 & 3.17 & Rp $\quad 6,000$ & Rp 18,000 & Rp 12,000 & Rp $\quad 150,000$ & $\mathrm{Rp} \quad 450,000$ & Rp $\quad 300,000$ & Low & Low & Dog \\
\hline 11 & $\begin{array}{l}\text { Roti } \\
\text { Maryam } \\
\text { Cheese } \\
\end{array}$ & 15 & 1.90 & Rp 7,992 & $\operatorname{Rp} 18,000$ & Rp 10,008 & Rp $\quad 119,880$ & $\operatorname{Rp} \quad 270,000$ & Rp $\quad 150,120$ & Low & Low & Dog \\
\hline & Total & 788 & & & & & $\operatorname{Rp} 8,000,947$ & Rp $17,066,000$ & Rp $10,700,053$ & & & \\
\hline \multicolumn{3}{|c|}{ Average CM } & $\begin{array}{l}\mathrm{Rp} \\
13,578.75 \\
\end{array}$ & & & & & & & & & \\
\hline \multicolumn{3}{|c|}{ Indeks Popularitas (\%) } & 6.36 & & & & & & & & & \\
\hline
\end{tabular}




\section{SIMPULAN DAN SARAN UNTUK PENELITIAN SELANJUTNYA}

Berdasarkan analisis yang telah dilakukan pada bab sebelumnya tentang indeks popularitas, marjin kontribusi, dan klasifikasi menu makanan di Kambing Soon Resto \& Café Bandung pada periode Maret - Agustus 2017, maka penulis membuat kesimpulan mengenai hasil analisis tersebut yaitu sebagai berikut:

1. Berdasarkan hasil analisis indeks popularitas dari setiap menu makanan dapat disimpulkan bahwa dari 32 menu makanan yang penulis teliti terdapat 18 items atau $56,25 \%$ termasuk dalam kategori yang memiliki indeks popularitas tinggi. Sedangkan 14 items atau sekitar 43,75\% masuk dalam kategori yang memiliki indeks popularitas rendah.

2. Berdasarkan dari hasil analisis marjin kontribusi dari setiap menu makanan dapat disimpulkan bahwa dari 32 menu makanan yang penulis teliti terdapat 11 items atau $34,38 \%$ termasuk dalam kategori dengan marjin kontribusi tinggi. Sedangkan 21 items atau $65,62 \%$ masuk dalam kategori dengan marjin kontribusi rendah.

3. Berdasarkan menu engineering worksheet, menu dikelompokan menjadi 4 klasifikasi yaitu Stars, Plowhorses, Puzzles, dan Dogs. Dengan melakukan pengelompokan tersebut maka pihak manajemen restoran dapat mengontrol menu yang mereka tawarkan dengan baik. Berdasarkan hasil analisis yang telah dilakukan dapat disimpulkan bahwa dari 32 menu makanan yang penulis teliti, menu tersebut diklasifikasikan sebagai berikut:

a. Kategori stars terdiri dari 7 menu dengan persentase sebesar 21,88\%. b. Kategori plowhorses terdiri dari 11 menu dengan persentase sebesar $34,37 \%$.

c. Kategori puzzles terdiri dari 4 menu dengan persentase sebesar 12,50\%.

d. Kategori $\operatorname{dog} s$ terdiri dari 10 menu dengan persentase sebesar $31,25 \%$.

4. Strategi pengembangan bisnis berbasis Menu Engineering di Kambing Soon Resto \& Cafe

a. Menu yang masuk dalam kategori stars (popularitas tinggi dan profitabilitas tinggi) merupakan menu unggulan baik. Bagi kelompok ini pihak Kambing Soon perlu menjaga kualitas menu tersebut, sehingga tetap menjadi idola bagi para pelanggan.

b. Menu yang masuk ke dalam kelompok plowhorses (popularitas tinggi namun profotabilitas rendah) dapat diperbaiki dengan meningkatkan harga jual. Bisa dengan melakukan inovasi sehingga bisa menaikkan harga jual. Namun jangan terlalu tinggi meningkatkan harga jual, karena bisa berpengaruh terhadap popularitas.

c. Untuk menu yang masuk ke dalam kelompok puzzles (popularitas rendah namun profitabilitas tinggi) dapat diperbaiki dengan melakukan promosi yang lebih untuk kelompok menu ini dan diskon atau dijadikan recommended menu untuk pelanggan.

d. Untuk menu yang masuk ke dalam kelompok dogs (popularitas dan profitabilitas rendah) pihak 
manajemen perlu melakukan peningkatan kembali terhadap menu tersebut dari segi rasa, penampilan, porsi, harga dan kualitasnya dan dapat melakukan inovasi menu dengan menggunakan bahan dasar yang sama. Langkah terakhir yang bisa dilakukan adalah menghapus menu di kategori ini dan mengganti dengan menu baru.

Pihak manajemen Kambing Soon Resto \& Café Bandung diharapkan untuk menerapkan menu engineering sebagai alat untuk memantau perkembangan menu dan melakukannya setiap periode, yaitu setiap 6 bulan. Sehingga, dapat mengetahui sejauh mana menu yang masih diinginkan oleh tamu. Pihak manajemen juga diharapkan memberikan pemahaman mengenai menu engineering kepada karyawan agar pemantauan perkembangan menu dapat terlaksana dengan baik serta diharapkan untuk lebih mengembangkan produk dengan bahan utama kambing.

\section{DAFTAR PUSTAKA}

Arikunto. Prosedur Penelitian : Suatu Pendekatan Praktek. Jakarta : PT. Rineka Cipta, 2006

Coltman, Michael M dan Martin G. Jagels. 2001. Hospitality Management Accounting, seventh edition . New York.

Dittmer, Paul R. 2003. Principles of Food, Beverage, and Labor Cost Control 7th ed. New York : John Wiley \& Sons.

Dittmer, Paul R, J. Desmond Keefe. 2009. Principle of Food, Beverage, and Labor Cost Control. Hoboken New Jersey : Jhon Wiley \& Sons.

Jagles, Martin G. Ralston, Catherine E. 2007. Hospitality Management Accounting. New Jersey : John Wiley $\&$ Sons.

Miller, Jack E, David R. Hayes dan Lea R. Dopson. 2002. Food and Beverage Cost Control. New York, John Wiley \& Sons.

Nawawi, Hadari. 2005. Metode Penelitian Bidang Sosial. Gadjah Mada University Press.

Ninemeir, Jack D. 1990. Management of Food and Beverage Operation. Michigan. The Educational Intitute of AHMA.

Ninemeier, Jack D. 2009. Planning and Control for Food and Beverage Operation. Michigan : The Educational Institute of AHMA.

Scanlon, Nancy L. 1992. Catering Menu Management. New York. Van Nostand Reinhold.

Scanlon, Nancy Loman. 2000. Catering Management. USA : John Wiley \& Sons

Schmidgall, Raymond S. 1997. Managerial Accounting. Michigan. The Educational Institute of American Hotel and Motel Association (AHMA).

Siagian, Sondang P. 1992. Fungsi - Fungsi Manajerial. Jakarta: Bina Aksara.

Spears, Gregoire Marry B. Food Service Organizations 5th ed. New Jersey : Pearson Education, 2004

Sugiyono. 2013. Metode Penelitian Administrasi. Jakarta : Alfabeta 
Sulaiman, Samsudin. 2013. Metodologi

Penelitian. Bandung : Enhaii pres 